\title{
Mapping the Capacity Building Process of a Corporate Social Responsibility Driven Agricultural Intervention in the Niger Delta Region, Nigeria.
}

\author{
Ekanem, J. T. ${ }^{1}$ and Inyang, E. B. ${ }^{2}$ \\ ${ }^{1}$ Department of Agricultural Economics and Resources Management. \\ Akwa Ibom State University (AKSU), Obio Akpa Campus, Oruk Anam, \\ Akwa Ibom State, Nigeria. Email: jemitim@yahoo.com \\ ${ }^{2}$ Department of Agricultural Economics and Extension. \\ University of Uyo, Uyo, Akwa Ibom State. \\ Email: embainy@yahoo.com
}

\begin{abstract}
This study mapped the outcomes of the agricultural intervention based on resultant effectiveness and functionality of capacity building process in SPDC's agricultural intervention programme in the Niger Delta region of Nigeria. Multi-stage sampling technique was used to select forty-eight (48) respondents for the study. Semistructured questionnaire was used for data collection and the data were analysed using descriptive statistics and composite index analysis. The result reveals that $64.6 \%$ of the respondents received training on various aspects of management of agricultural project such as, feed production, machine operation and maintenance, farm maintenance and general project management. Result from field observation shows that $31.25 \%$ of the intervention was functional. The result of data analysis shows that, $75 \%$ of the respondents indicated they needed practical capacity building for effective project management and sustainability. The findings support a dire need for participatory evaluation on strategies towards the improvement of capacity building process service delivery.
\end{abstract}

Key Words: Human capital, capacity building, agricultural intervention, SPDC,

\section{Introduction}

Planned change actions or intervention programmes are always associated with resultant effects and the actions are bound to be accompanied with desirable and or undesirable results (Scriven,1967 and Isiugo-Abanihe and Inyang 2007). Furthermore, Inyang, Eka, Udoma and Okon (2004) noted that some of the resultant outcome(s) can be very salient and thus may require some level of skilful efforts to deduce lessons quite needed for knowledge sharing among planners for future development programming towards achieving sustainable transformation of most especially, developing society. Outcome mapping as a concept is being popularised within the development programme evaluation community and it is being used as a tool for dealing with complexity in planning, monitoring and evaluating development, humanitarian and social interventions. It is flexibly embedded in formative and summative techniques of evaluation that are very essential in investigating the direction and magnitude of assistance implementation's effectiveness. Its typical utilization applies in a study of this nature that is characterized by multiple stakeholders with salient expectations that may slightly differ in reality even though the capacity building process was considered by the major initiative driver as a sine qua non towards ensuring sustainable human capital and agricultural transformation of communities within its operational area. Performance of projects can be expressed as the output when considering physical item whether for a long or short-term project and outcomes when associated with changing status of humans in 
terms of their knowledge, skill, behavioural and generally his or her socioeconomic wellbeing for either short or long-term. Therefore, effectiveness evaluation of capacity building process of a corporate social responsibility driven agricultural intervention in the Niger Delta region, Nigeria becomes inadvertently necessary since projects differ in performances.

Naturally, effectiveness means goal attainment. Community development effectiveness is seen as the degree to which projects achieve their goals. It can be described as the extent to which the desired level of outcome is achieved. According to UNDP (2001) development effectiveness reflects the extent to which an intervention has brought about targeted change in the life of the individual beneficiary. This form of effectiveness is influenced by various factors beginning with the quality of project design and ending with the relevance and sustainability of desired results. Measuring development effectiveness is an exercise in tracking progress towards development goals; the interest lies on whether the immediate goals of assistance or intervention have been achieved. This knowledge is therefore necessary for purposes of evaluating sustainability of which outcome mapping becomes an unavoidable tool. Vodouche (1996) reveals that lack of effective accountability mechanisms was one of the major factors that undermined the effectiveness of rural development organizations. UNDP (2001) puts it that project evaluations are focused on the quality of design and implementation and on the achievement of outputs and immediate objectives, as such, the evaluations remain a limited snapshot of development effectiveness; though evaluations do provide information on the impact of the given projects on target groups, which can be considered a useful approximation of development effectiveness. Much concerted efforts directed towards development of the Niger delta region of Nigeria. Previously, all tiers of government in Nigeria were implementing their programmes and project, which some are donated and are driven by international agencies. As the society have noted that government cannot handle all development challenges alone, there has been growing participation of the multinational companies towards driving development in the Niger Delta region of Nigeria.

The Niger Delta region of Nigeria is among the largest productive wetlands ecosystem in Africa and also the most important wetlands and marine ecosystems in the world, comprising a vast flood plain formed over several years by the accumulation of sedimentary deposits washed down the Niger and Benue Rivers. As asserted by Twumasi and Merem, (2006) and Uyigue and Agho (2007), the Niger Delta region has a steady growing population of approximately 30 million people as of 2005 , accounting for more than $23 \%$ of Nigeria's total population. UNDP's report of 2006 stated that about 33 million people are in this region, and from this report also the figure is expected to rise to 46 million in 2020 with the oil industry as a key contributor to the surge in population. There are many multilateral oil companies in the region, despite its positive contributions to Nigerian economy its resultant negative consequences in terms of socioeconomic life have led to some level tension and restiveness among the inhabitants. The re-occurrence and depth of insecurity events in the Niger Delta region has depicted or painted a peculiar development intervention unfriendly climate, which require sensitive and tactical application development planning and implementation by development administration professional if sustainability skills and tools are at the centre of development objectives.

In the midst of uncertainties within the region, many development strategies and efforts had been witnessed by the inhabitants. These efforts had been initiated from different sources, all with the aim of empowering and improving the quality of life of the locals and most affected by the industrially induced human perturbations in the region. Of course, major projects have involved massive land takes, relocation of families, noise pollution and there have been incidents of oil spills on arable lands, rivers and creeks, generating lots of agitations and quarrels among the inhabitants. In view of this situation, alternative means of 
livelihood is required to cushion the effect of deprived primary occupations. It has to ameliorate the adverse living standards amongst the people as worsened by widespread poverty. Therefore, SPDC thought it wise to put in place an appropriate community development programme in order to create an enabling environment over time. This is why SPDC, as part of its corporate social responsibility (CSR) coupled with the demands by the people of the region, has been compelled to strenuously contribute to the development of the region. SPDC has embarked upon massive intervention programmes in the Niger Delta region especially in the three core areas of her operation through its social performance and community relations (SPCR) department. These projects have the sole objective of achieving set of outcomes. Such objectives include; promoting and sustaining wealth creation activities at micro, small and medium enterprise levels; which specifically seek to increase opportunities for wealth creation; Build community capacity for sustainable development and promote peace and security among others. The focus therefore, was on training of members of the project management committees (PMCs) to build their capacities for effective project' management and sustainability. Inyang et al (2004) had observed suboptimal operations of some laudable intervention programme which in most cases did not meet expected programme performance. Could this assertion apply to this agricultural intervention under investigation or what have been the outcomes of SPDC Community Development Programme in this region and also the capacity building process with respect to the agricultural intervention that had been in existence between 2004 and 2008. Capacity building programme is one of the veritable means of empowering local institutions and individuals to champion their desired improvement with respect to socioeconomic wellbeing status. It is strictly unavoidable in the agricultural transformation process. This is part of the reasons SPDC in her agricultural intervention's community development programmes emphasizes capacity building at the grassroots. Have the resultant outcomes of this capacity building process been mapped? To what extent has the performance indicators been measured? Thus, this paper analysed

1. background characteristics of the respondents;

2. functionality of the intervention's initiative;

3. various components of human capacity building; and

4. level of performance of the intervention.

\section{Methodology}

\section{Study Area}

The study was carried out in the Niger Delta region of Nigeria. It is endowed with abundant natural resources; large crude oil and gas deposits, extensive forests, good agricultural land and rich fish resources. The region has four ecological zones which are: the sandy coastal ridge barrier (uplands), mangroves; freshwater swamp forests; and lowland rainforests. Niger Delta region of Nigeria is situated in the humid tropics areas where differences in mean annual temperatures between three warmest and three coldest months are less than $5{ }^{\circ} \mathrm{C}$. It lies between longitudes $4^{\circ} 18^{\prime \prime}$ and $9^{\circ} 24^{\prime \prime} \mathrm{E}$ of the Greenwich Meridian and latitudes $4^{\circ} 12^{\prime \prime}$ and $7^{\circ} 48^{\prime /} \mathrm{N}$ of the equator. It is made up of 9 states with 188 Local Government Areas and over 40 ethnic groups in 3,000 communities. The coastal states include huge areas mainly accessible by boat. Bayelsa, Rivers and Cross River states have extensive coastlines and artisanal fishing is the major rural economic activity. From the 2006 census figure, the population of Niger Delta region is estimated at 31,277,901 million (NPC, 2006). SPDC's operations centre on the core Niger Delta states of Rivers, Bayelsa and Delta. 


\section{Sampling Procedure and Data Collection}

The target population for this study consisted of all the beneficiaries of SPDC's agricultural intervention training in the Niger Delta communities particularly the project management committee members. The project management committee members (PMC) were community beneficiaries selected by the communities to be trained by the NGOs for take -over of projects' management at the exit of the NGOs. The study used multi-stage sampling technique. At first stage, purposive sampling technique was used to select SPDC's core operational communities which were, communities in Rivers, Bayelsa and Delta states. At the second stage, a purposive sampling technique was employed to select interventions executed by Economic Empowerment Unit of Sustainable Development and Community Relations (SDCR) team. At the third stage, a total of 16 out of 32 agricultural projects implemented and completed within the period under study (2004-2008) were selected by simple random sampling technique for the purpose of getting a representative sample. At the fourth stage, three (3) Project Management Committee (PMC) members out of five (5), were randomly selected per project and interviewed. A total of forty-eight (48) respondents out of eighty (80), were sampled for the study. Primary data were collected by administration of semi-structured questionnaire on the respondents as well as participant field observation. Data were analyzed using descriptive statistics.

\section{Results and Discussion}

\section{Background Characteristics of the Respondents}

With reference to Table 1 , the mean age was 41.8 years. This means that the composition of the project management committee had relatively young and active people who were willing to direct and help their communities towards gaining individuals and collective benefits (Adesope, Asiabaka, and Angba, 2003). The distribution of respondents by educational status revealed that there was relatively high literacy rate among the respondents as most of them had basic education. Interestingly, 58 percent of them had tertiary education. Educational attainment of respondents is a significant indicator to their ability to understand what is taught especially during the capacity building sessions, to adopt and use it effectively. He can also receive information, understand and share his experiences and knowledge with others with formal education. Highly educated farmers also tend to adopt technology with greater intensity. They also tend to possess higher analytical capability of the information and knowledge necessary to successfully implement new technology and realize expected results (Akpofure and Ojile, 2003; Adesope, Odurukwe, Ugwoke and Amaji, 2004; Ugwoke, Adesope, and Ibeh, 2005 and Uematsu and Mishra, 2010). This means that since a greater percentage of the beneficiaries were educated, it was expected that the adoption of introduced project would not be a problem.

Another background characteristic that was worth our consideration was the household size, which is an indication of the pressure on income of the household. Generally, a household size range of $1-6$ with the parents inclusive is recommended by the Nigerian Government. In a demographic report by NPC (2006), the average household size in Nigeria is 5.0 persons though the number is slightly higher in rural areas than in urban areas. The finding reveals that, the mean household size was 5.6 (Table 1). The study went further to understand which kind of people were among the project management committee, particularly, if their livelihoods were oriented towards agriculture. The findings further affirmed that majority of primary economic activities of rural folks are agricultural in nature. The agricultural intervention was not placed in wrong managers' hands within the communities. 
Table 1: Distribution of respondents based on background characteristics

\begin{tabular}{|c|c|c|c|}
\hline Item & Variables & Frequency & Percentage \\
\hline \multirow[t]{5}{*}{1} & Age & & \\
\hline & $20-40$ & 26 & 54.1 \\
\hline & $41-60$ & 17 & 35.5 \\
\hline & Above 60 & 5 & 10.4 \\
\hline & Mean Age $=41.8$ & & \\
\hline \multirow{5}{*}{2} & Educational status & & \\
\hline & FLSC & 5 & 10.2 \\
\hline & GCE/SSCE & 15 & 31.3 \\
\hline & NCE/OND & 11 & 23.0 \\
\hline & B.Sc/HND & 17 & 35.5 \\
\hline \multirow[t]{5}{*}{3} & Household Size & & \\
\hline & $1-3$ & 8 & 16.7 \\
\hline & $4-6$ & 25 & 52.1 \\
\hline & $7-9$ & 15 & 13.2 \\
\hline & Mean $=5.4$ & & \\
\hline \multirow[t]{4}{*}{4} & Occupation & & \\
\hline & Agriculture & 41 & 85.4 \\
\hline & Business & 5 & 10.4 \\
\hline & Any other & 2 & 4.2 \\
\hline
\end{tabular}

Source: Field survey, 2011

Functionality of SPDC's agricultural intervention

The functionality of the intervention's initiative is shown in Table 2 where two, out of eight aquaculture projects implemented by SPDC in the study area were functional. Also, out of four poultry projects, three were functional while none of the three cassava processing mills were functional and the only rice processing mill was not functional also. On the whole five projects were functional while eleven were not. By this result, it means that, $31.25 \%$ of all the agricultural intervention was functional while $68.75 \%$ was not. This shows that the project did not achieve its purpose as envisaged. It is worth noting that this table represents the observation at the dates of field survey. It therefore represents the true position of the projects.

Table 2: Distribution of agricultural projects based on functionality

\begin{tabular}{lcccccc}
\hline Project Type & $\begin{array}{l}\text { Number of } \\
\text { Projects }\end{array}$ & \multicolumn{2}{c}{ Functional } & \multicolumn{2}{c}{ Non-Functional } & Total \\
\cline { 2 - 6 } & Freq & $\%$ & Freq & $\%$ & \\
\hline Aquaculture & 8 & 2 & $(25)$ & 6 & $(75)$ & 100 \\
Cassava Mill & 3 & 0 & $(0)$ & 3 & $(100)$ & 100 \\
Rice Mill & 1 & 0 & $(0)$ & 1 & $(100)$ & 100 \\
Poultry & 4 & 3 & $(75)$ & 1 & $(25)$ & $\mathbf{1 0 0}$ \\
\hline
\end{tabular}

Source: Field survey, 2011

Assessment of various components of human capacity building.

The result in Table 3 reveals that training received was on four components namely; feed production, machine operation and maintenance, farm maintenance and general project management. Majority of the respondents $(33.3 \%)$ received training on how to 
manage projects for sustainability, $14.6 \%$ received training on farm maintenance and $8.3 \%$ each received training on feed production and machine operation/maintenance.

However, $35.4 \%$ of the respondents did not receive any form of training yet they were managing project which they knew little or nothing about. Considering the fact that, NGOs had as key in the contract terms to carry out business literacy training (BLT) for the PMC members, also one of the SPDC's project objectives was to build community capacity for sustainable development, the sponsors may have not achieved their aims at capacity building which invariably may have been a factor in projects functionality. Inadequate capacity building may have contributed to the greater percentage of non functional projects. This is so because continuous and consistent training builds and strengthens capacity for continued good management practices and project performance. It may imply that, SPDC should factor in periodic training mechanism to close the gaps in the knowledge and skills needed for effective and sustainable interventions and to also keep pace with the changing technology.

Table 3: Distribution of respondents based on components of capacity building

\begin{tabular}{lll}
\hline Item & Capacity Building & Percentage \\
\hline 1 & Project management & 33.3 \\
2 & Farm maintenance & 14.6 \\
3 & Feed production & 8.3 \\
4 & Machine operation & 8.3 \\
5 & No training & 35.4 \\
\hline Total & & $\mathbf{1 0 0}$
\end{tabular}

Source: Field Survey, 2011

\section{Assessment of performance of SPDC's agricultural intervention}

As shown in Table 4, $89.6 \%$ of the PMC members affirmed that the agricultural intervention was well funded by SPDC. About $48.0 \%$ confirmed that they received adequate training which built up their capacity to sustain the projects but $73.0 \%$ stated that they needed more training. The result further revealed that $16.7 \%$ and $31.3 \%$ agreed to receive adequate supervision from SPDC and NGOs respectively while $39.6 \%$ stated that the projects were on-going. Furthermore, $35.4 \%$ affirmed that the project was profitable and $31.2 \%$ of the beneficiaries also affirmed that projects did employ adequate number of staff. Again, $41.7 \%$ of the respondents stated that the projects were generating enough income and $62.5 \%$ of the beneficiaries accepted keeping business transaction records. Also, $35.4 \%$ each of the beneficiaries agreed that they can recommend the project to other people and that, SPDC's agricultural intervention has achieved its purpose while $39.6 \%$ affirmed that the project will go beyond the next 5 years. Ranking the responses shows that majority of the respondent attested to proper funding of the projects by sponsor (SPDC) but the low percentages of other performance indicators suggested that, beyond funding, other factors including capacity building are key to project functionality, performance, sustainability and the overall objective of poverty alleviation and indeed agricultural transformation. 
Table 4: Distribution based on the level of performance of SPDC's agricultural intervention.

\begin{tabular}{|c|c|c|c|c|}
\hline Item & Indicators & Agree & Disagree & Rank \\
\hline 1 & Project is well funded by SPDC & $43(89.6)$ & $5(10.4)$ & $1^{\text {st }}$ \\
\hline 2 & Project is on-going & $20(41.7)$ & $28(58.3)$ & $5^{\text {th }}$ \\
\hline 3 & $\begin{array}{l}\text { I received adequate training for the project } \\
\text { from sponsors }\end{array}$ & $23(48.0)$ & $25(52.0)$ & $4^{\text {th }}$ \\
\hline 4 & I need more training for the project & $35(73.0)$ & $13(27.0)$ & $2^{\text {nd }}$ \\
\hline 5 & $\begin{array}{l}\text { I received adequate supervision from the } \\
\text { sponsors }\end{array}$ & $8(16.7)$ & $40(83.3)$ & $9^{\text {th }}$ \\
\hline 6 & $\begin{array}{l}\text { I received adequate supervision from the } \\
\text { NGO }\end{array}$ & $15(31.3)$ & $33(68.7)$ & $8^{\text {th }}$ \\
\hline 7 & I have the required number of staff & 15(31.3) & $33(68.7)$ & $8^{\text {th }}$ \\
\hline $\begin{array}{l}8 \\
9\end{array}$ & $\begin{array}{l}\text { Project is generating income } \\
\text { Project is profitable }\end{array}$ & $\begin{array}{l}20(41.7) \\
17(35.4)\end{array}$ & $\begin{array}{l}28(58.3) \\
31(64.6)\end{array}$ & $\begin{array}{l}5^{\text {th }} \\
7^{\text {th }}\end{array}$ \\
\hline 10 & I keep record of my business transactions & $30(62.5)$ & 18(37.5) & $3^{\text {rd }}$ \\
\hline 11 & $\begin{array}{l}\text { I can recommend the project to another } \\
\text { person(s) }\end{array}$ & $17(35.4)$ & $31(64.6)$ & $7^{\text {th }}$ \\
\hline 12 & The project will go beyond the next 5 years & $19(39.6)$ & $29(60.4)$ & $6^{\text {th }}$ \\
\hline 13 & $\begin{array}{l}\text { The intervention by SPDC has achieved its } \\
\text { purpose }\end{array}$ & $17(35.4)$ & $31(64.6)$ & $7^{\text {th }}$ \\
\hline
\end{tabular}

Source: Field Survey, 2011

\section{Conclusion and Recommendation}

It could be observed that despite the level of education attained by the respondents, there is obvious need for tailor - made capacity building especially in technical aspect without which an investment can run aground. Funding is part of the process but not everything. Apart from provision of training, there is strong need for mainstreaming of theory of change (outcome mapping) to enable adequate isolation of the unintended and intended outcomes of programme. SPDC should factor in periodic training mechanism to close the gaps in the knowledge and skills needed for effective and sustainable interventions and to also keep pace with the changing technology in order to bring about the needed agricultural transformation.

\section{References:}

Adesope, O.M., Asiabaka, C.C.,\& Angba ,A.O. (2003). Appraisal of youths participation in selected communities of Ogbaland, Rivers State. Journal of Sustainable Tropical Agricultural Research, 7: 12-16

Adesope O.M., Odurukwe, S.N., Ugwoke, F.O., \& Amaji, P.O. (2004). Youth involvement in small scale agricultural enterprises in Mbaise area of Imo State, Nigeria. Journal of Agriculture, Forestry and the Social Sciences, 2(2): 28-34.

Akpofure, E.A., and Ojile, M., (2003). "Social Impact Assessment: An interactive and participatory approach" in UNEP EIA Training Resource Manual, pp 211-222 online web http://www.iaia.org/Non-Members/EIA/case studies/SIAA approach. Accessed on 30.04.2010

Isiugo-Abanihe, I. M. and E. B. Inyang(2007): Dynamics of Psychological Variables on the Preparedness towards Implementation of HIV/AIDS-Agricultural Intervention 
Programme. West African Journal of Health and Physical Education(WAJOPHE). 11: 53-66.

Inyang, E. B., Eka, I. E., Udoma, G. M. and Okon, O. (2004). Attitudinal Dispositions and Sustainable Management Likelihood of Degrading Wetland Forest Resources in a Niger Delta Region, Nigeria, pp 305-309. In: Baumgartner, David M; (ed). Human Dimensions of Family and Farm Forestry. International Symposium Proceedings of Washington State University Extension. March 29 -April 1, Pullman, Washington, USA.

National Population Commission (2006). Census Report of Nigeria. Population and Development Review Vol. 33, No. 1 (Mar., 2007), pp. 206-210 Published by: Population Council Article Stable URL: http://www.jstor.org/stable/2543460110.2307/25434601

Scriven, M. (1967). The methodology of evaluation. In R. W. Tyler, R. M. Gagne, \& M. Scriven(Eds.), Perspectives of curriculum evaluation, 39-83. Chicago, IL: Rand McNally.

Twumasi, Y. and Merem E (2006). GIS and Remote Sensing Applications in the Assessment of Change within a Coastal Environment in the Niger Delta Region of Nigeria. International Journal of Environmental Research \& Public Health, 3:1, 98-106. www.ijerph.org

Uematsu, H. And Mishra. K. (2010). Can Education Be a Barrier to Technology Adoption? Selected Paper prepared for presentation at the Agricultural \& Applied Economics Association 2010 AAEA,CAES, \& WAEA Joint Annual Meeting, Denver, Colorado, July 25-27, 2010

Ugwoke, F.O., Adesope, O.M.,\& Ibeh, F.C. ( 2005). Youth participation in farming activities in rural areas of Imo State, Nigeria: Implications for Extension. Journal of Agricultural Extension, 8: 136-142.

UNDP (2001). Development effectiveness: review of evaluation effectiveness. www.undp.org/oe/documents/der2001.(November, 2001) accessed on March, 2013.

Uyigue, E. and Agho, M (2007). Coping with Climate Change and Environmental Degradation in the Niger Delta of Southern Nigeria. Community Research and Development Centre Nigeria (CREDC).

Vodouche, S. D. (1996). Making Rural Development Work. Cultural Hybridisation of Farmers' Organizations - The Adja Case in Benin. Published in Wageningen. P. 172. 